\title{
Respiratory Syncytial Virus in Hospital Cross-infection
}

\author{
R. K. DITCHBURN, JOYCE MCQUILLIN, P. S. GARDNER, S. D. M. COURT
}

British Medical fournal, 1971, 3, 671-673

\section{Summary}

During an epidemic of respiratory syncytial (R.S.) virus in Newcastle upon Tyne 13 children developed R.S. virus infections while in hospital with other conditions. R.S. virus infection was also noted in four members of the staff. In two of the hospital wards outbreaks developed. All children infected with R.S. virus developed symptoms. The symptoms varied with age; two children aged 2 months or less developed colds, as did five children over 1 year of age. One child of 15 months with WerdnigHoffman disease, though suffering from a cold, later developed pulmonary collapse. All five children aged 3 to 8 months developed bronchiolitis. The effectiveness of special nursing in cubicles was probably diminished because adults with mild colds were excreting virus. The dangers of R.S. virus infection to other children in the ward, especially those with congenital heart disease, is emphasized.

\section{Introduction}

The clinical syndromes which are now associated with respiratory syncytial (R.S.) virus infection have been defined over the last decade in many studies of children admitted to hospital with acute respiratory infections (Beem et al., 1960; Chanock et al., 1961; McClelland et al., 1961; Holzel et al., 1963, 1965; Gardner, 1968). These have recently been enlarged by a description of the illnesses produced by this virus in newborn infants in a maternity hospital (Neligan et al., 1970) and in families (Hurrell et al., 1971). The largest epidemic of R.S. virus so far recorded in Newcastle occurred in the first two months of 1971, and this provided an opportunity to study the contribution of this virus to cross-infection in children's wards.

The questions which we wanted to answer were these:

Does R.S. virus spread to uninfected children in a children's ward? If it does, what types of illness follow, and is their severity related to the age of the child?

What is the incubation period? For how long is virus excreted before and after the development of respiratory symptoms?

University of Newcastle upon Tyne and Royal Victoria Infirmary, Newcastle upon Tyne NE1 4LP

R. K. DITCHBURN, M.B., D.C.H., Senior Research Associate, Departments of Child Health and Virology

JOYCE McQUILLIN, B.SC., F.I.M.L.T., Senior Scientific Officer, Department of Virology

P. S. GARDNER, M.D., DIP.BACT., Consultant Virologist and Honorary Reader

S. D. M. COURT, M.D., F.R.C.P., Professor of Child Health
Infants and many young children are nursed in cubicles. Do these provide a protective barrier?

We know from the work of Kravetz et al. (1961) and Johnson et al. (1962) that when adults with serological evidence of previous infection with R.S. virus are reinfected artificially or naturally mild respiratory illness may occur. What part do such infected adults play in the network of cross-infection?

\section{Methods}

All children admitted to Newcastle upon Tyne hospitals with acute respiratory tract infection are investigated for a virus aetiology. Cough swabs and nasopharyngeal secretions are taken and both types of specimens are cultured on HeLa, HEp 2, monkey kidney cells, and a human diploid cell line (W.I.38). Cells in nasopharyngeal secretions are examined by the fluorescent antibody technique for the presence of R.S. and other respiratory virus antigens. The methods used have been fully described elsewhere (Sturdy et al., 1969; McQuillin et al., 1970; Gardner et al., 1971). These same methods were applied to children who developed either upper or lower respiratory tract symptoms after admission to hospital. When evidence of crossinfection occurred in one of the wards cough swabs were taken from all asymptomatic contacts. It was impractical to obtain nasopharyngeal secretions from asymptomatic children because they have little secretion present. Cough swabs were obtained from five members of the medical and nursing staff who developed respiratory symptoms during the outbreak in the wards, and from two of them nasopharyngeal secretions were also obtained.

\section{Results}

During the winter 1970-1 22 children developed acute respiratory infections while in hospital with conditions which were not of a virus origin. The virus aetiology of these acute respiratory infections is shown in Table I. R.S. virus was the virus most often associated with respiratory infection and accounted for 13 $(59 \%)$ of the 22 cases. The clinical details of the 13 children from whom R.S. virus was isolated after admission to hospital are shown in Table II; it lists the clinical condition for which the

TABLE I-Viruses Isolated from Patients whose Respiratory Illnesses began after Admission to Hospital (November 1970 to March 1971)

\begin{tabular}{|c|c|c|c|c|c|c|}
\hline \multicolumn{5}{|c|}{ Virus } & \multirow{2}{*}{\begin{tabular}{|c|} 
No. of Cases \\
13 \\
2 \\
1 \\
6 \\
\end{tabular}} & \multirow{2}{*}{$\begin{array}{c}\% \\
59 \\
9 \cdot 1 \\
4 \cdot 6 \\
27 \cdot 3\end{array}$} \\
\hline $\begin{array}{l}\text { Respiratory syncytial virus } \\
\text { H-strain rhinovirus } \ldots \\
\text { Parainfluenza virus type } 1 \\
\text { No virus isolated }\end{array}$ & $\begin{array}{l}\cdots \\
\cdots \\
\cdots\end{array}$ & $\begin{array}{l}\cdots \\
\cdots \\
\cdots\end{array}$ & $\begin{array}{l}\ldots \\
\because \\
\cdots\end{array}$ & $\begin{array}{l}\cdots \\
\cdots \\
\cdots\end{array}$ & & \\
\hline Total & .. & .. & $\ldots$ & $\ldots$ & 22 & 100 \\
\hline
\end{tabular}

TABLE II-Clinical Features of 13 Children with R.S.V. Infections Starting in Hospital

\begin{tabular}{|c|c|c|c|c|c|c|c|}
\hline Case No. & $\begin{array}{l}\text { Age in } \\
\text { Months }\end{array}$ & Sex & Hospital & Admission Diagnosis & Site in Ward & $\begin{array}{c}\text { Days in Hospital } \\
\text { before R.S.V. Illness }\end{array}$ & Diagnosis of R.S.V. Illness \\
\hline $\begin{array}{r}1 \\
2 \\
3 \\
4 \\
5 \\
6 \\
7 \\
8 \\
9 \\
10 \\
11 \\
12 \\
13\end{array}$ & $\begin{array}{r}20 \\
38 \\
15 \\
3 \\
8 \\
3 \\
40 \\
13 \\
5 \\
2 \\
5 \\
1 \\
19\end{array}$ & $\begin{array}{l}\mathrm{F} \\
\mathrm{M} \\
\mathrm{F} . \\
\mathrm{F} \\
\mathrm{F} \\
\mathrm{M} \\
\mathrm{M} . \\
\mathrm{F} \\
\mathrm{M} \\
\mathrm{M} . \\
\mathrm{F} \\
\mathrm{M} \\
\mathrm{M}\end{array}$ & $\begin{array}{l}1 \mathrm{~A} \\
1 \mathrm{~A} \\
1 \mathrm{~A} \\
1 \mathrm{~A} \\
1 \mathrm{~A} \\
1 \mathrm{~B} \\
1 \mathrm{~B} \\
2 \\
2 \\
3 \\
3 \\
4 \\
5\end{array}$ & $\begin{array}{l}\text { Small stature } \\
\text { Septic arthritis } \\
\text { Werdnig-Hoffman } \\
\text { Vomiting } \\
\text { Failure to thrive } \\
\text { Urinary infection } \\
\text { Malnutrition } \\
\text { Cerebral atrophy } \\
\text { Meningitis } \\
\text { Melaena } \\
\text { Gastroenteritis } \\
\text { Social problem } \\
\text { Hypospadias }\end{array}$ & $\begin{array}{l}\text { Ward } \\
\text { Ward } \\
\text { Ward } \\
\text { Cubicle } \\
\text { Cubicle } \\
\text { Cubicle } \\
\text { Ward } \\
\text { Cubicle } \\
\text { Cubicle } \\
\text { Cubicle } \\
\text { Cubicle } \\
\text { Cubicle } \\
\text { Cubicle }\end{array}$ & $\begin{array}{r}33 \\
15 \\
40 \\
18 \\
33 \\
58 \\
61 \\
14 \\
9 \\
34 \\
3 \\
6 \\
4\end{array}$ & $\begin{array}{l}\text { Cold } \\
\text { Cold } \\
\text { Cold (pulmonary collapse) } \\
\text { Bronchiolitis } \\
\text { Bronchiolitis } \\
\text { Bronchiolitis } \\
\text { Cold } \\
\text { Cold } \\
\text { Bronchiolitis } \\
\text { Cold } \\
\text { Bronchiolitis } \\
\text { Cold } \\
\text { Cold }\end{array}$ \\
\hline
\end{tabular}


patient was admitted to hospital and also the respiratory syndrome which was associated with the acquired R.S. virus infection. There were seven males and six females whose ages ranged from 1 to 40 months; 12 of the 13 were admitted with non-respiratory conditions. One child (Case 1), though admitted for investigation of small stature, was found to have a severe cough. On admission parainfluenza virus type 2 was isolated, but R.S. virus was not present. She remained in hospital for detailed investigation, and 33 days after admission developed a cold associated with R.S. virus infection.

Four of the 13 children infected with R.S. virus were in beds in the ward and nine in cubicles because they were less than 1 year of age. The length of time in hospital before they developed R.S. virus infection varied from 3 to 61 days, and nine had been in hospital for two weeks or longer before the onset of their respiratory symptoms. The seven children with illnesses diagnosed as colds had rhinorrhoea, red fauces, and a cough; none developed signs of lower respiratory tract involvement. The criteria for the diagnosis of acute respiratory tract syndromes have been described elsewhere (Gardner, 1968). With one exception, the illnesses which followed cross-infection with R.S. virus were either common colds or bronchiolitis. All five children with bronchiolitis were in the age range of 3 to 8 months. The colds occurred either in the very young infant or in children over 8 months of age. The one exception was a child of 15 months with Werdnig-Hoffman disease, a condition where diminished ventilation predisposes to respiratory infections and pulmonary collapse.

Table II covers five hospitals. Cross-infection, however, occurred mainly in two wards. Cases 1 to 5 (Table II) occurred in ward A of hospital 1 in January 1971. Ward A is made up of two sections separated by a 20-yard (18-metre) corridor. Section 1 accepts children of 5 years and older, while section 2 accepts infants and children up to the age of 4 years. This latter section contains four cubicles and seven ward cots and beds. The outbreak of R.S. virus infection was confined to this section of the ward and its course is shown in the Chart. Of the eight infected children, R.S. virus infection was present on admission in three (A.B., C.D., and E.F.) and the remaining five (Cases 1-5, Table II) acquired the infection while in the ward. Three members of the ward staff-a staff nurse, a registrar, and a student-developed colds during the outbreak and R.S. virus was isolated from all three. Six other children were admitted to the wards in the latter part of this outbreak and while R.S. virus was still present in the ward, but none developed symptoms, and cough swabs taken twice weekly remained negative for R.S. virus. All the children from whom R.S. virus was isolated had respiratory symptoms. Once the outbreak had started specimens were taken frequently from all children in this ward, and in one (Case 5) R.S. virus was first

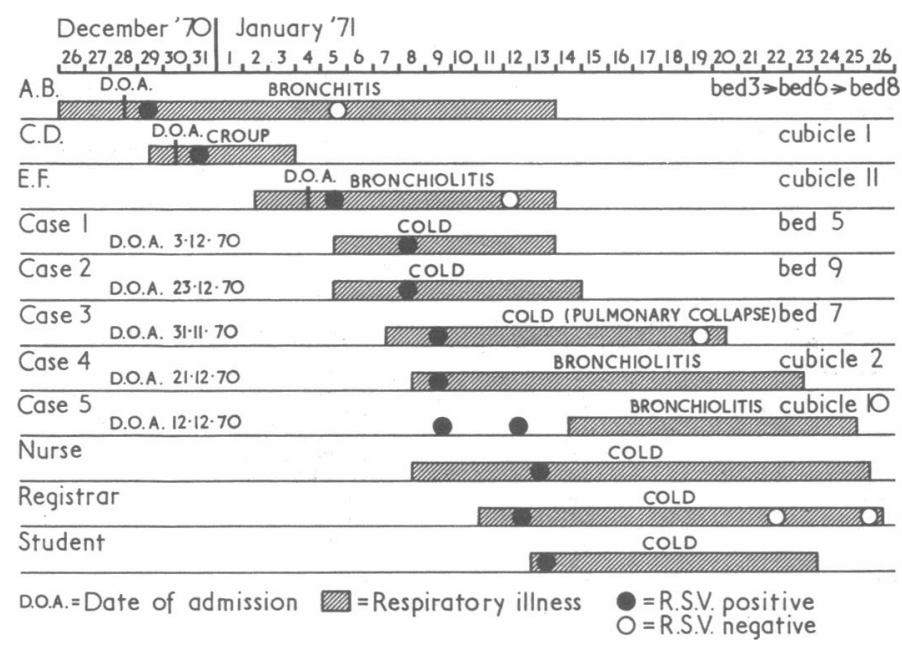

The outbreak in hospital 1, ward A. isolated five days before the symptoms of bronchiolitis developed.

A smaller outbreak occurred in the ward of hospital 2, in which children with R.S. virus infection were being continually admitted. Among them were two patients in adjacent cubicles; one had been in for 14 days and was being investigated for cerebral atrophy, and the other for nine days with meningococcal meningitis. Both these children acquired an R.S. virus infection, the first developing a cold and the second bronchiolitis. During the week before their infection the resident looking after them developed a cold which lasted a week, and on the first day of her illness R.S. virus was isolated from secretions taken from her nasopharynx.

\section{Discussion}

R.S. virus is the most frequent cause of acute respiratory infection of childhood (Chanock et al., 1961; Holzel et al., 1963, 1965; Gardner, 1968). It is not surprising, therefore, that in the present study it has been found to be the virus most often associated with respiratory infections developing in children already in hospital. R. S. virus was found in $13(59 \%)$ of the 22 cases studied (Table I). The incubation period of R.S. virus infection is not known with certainty and therefore two of these 13 cases may have been incubating infection when admitted.

In experimentally infected adult volunteers the incubation period was found to be five days (Kravetz et al., 1961; Johnson et al., 1962) but it is uncertain whether these findings apply to naturally acquired infections in infants and children. In two separate studies of outbreaks of R.S. virus infection in special care newborn nurseries the youngest babies infected in each study were 10 days old (Breton et al., 1961; Neligan et al., 1970). We can assume therefore that the incubation period is not more than 10 days, and in the present study from the interval between known R.S. virus-infected cases being admitted to the wards and the occurrence of infection in contacts (see Chart) a period of from five to eight days would seem reasonable. Nine of the 13 children (Cases 1-8 and 10, Table II) developed symptoms two weeks or longer after admission to hospital. These children without doubt acquired their virus infection while in the wards. Two (Cases 9 and 12) who had been in hospital nine and six days respectively before developing respiratory symptoms almost certainly had infections acquired in hospital. Two children (Cases 11 and 13) had been in hospital for three and four days respectively when they first developed respiratory symptoms. They probably acquired their infections at home and were incubating the virus at the time of admission.

Of the nine children who developed symptoms 14 days or more after admission, five (Cases 1 to 5) occurred in a single outbreak of R.S. virus infection in ward A, hospital 1. At the onset of this outbreak there were three children in the ward who had been admitted because of acute respiratory tract infection caused by R.S. virus. Two of them (C.D. and E.F.) were in cubicles where special precautions against cross-infection were taken. The remaining child (A.B.), being over 1 year of age, was in a bed and was moved to different parts of the ward several times during his illness. $\mathrm{He}$ is considered the most likely source of this outbreak. There were three other children in ward beds at that time and they all subsequently developed respiratory symptoms associated with R.S. virus infection. The time intervals between the admission of A.B. and the start of symptoms in these three children (Cases 1,2, and 3) were 8,8 , and 10 days respectively. Cases 4 and 5 were in cubicles but despite this, they both developed bronchiolitis 11 and 17 days respectively after the admission of A.B. The immediate source of infection of these two cases is not clear since they had no direct contact with the ward cases.

The staff nurse, registrar, and student developed respiratory symptoms 11,14 , and 16 days respectively after the admission of A.B. They came into regular contact with all the ward 
patients and may have acquired the infection from any of the cases. These members of staff were more likely to be part of the outbreak than the cause of it, but three other members of the ward staff who were not virologically examined had similar coryzal symptoms several days before the development of R.S. virus infections in the patients in the cubicles. Members of staff may therefore have been the source of infection in Cases 4 and 5. Similarly, in hospital 2, two infants who acquired R.S. virus infection in adjacent cubicles (Cases 8 and 9) may have been infected by the houseman who had a cold which was associated with R.S. virus excretion in the week before their illness. Cases 6, 7, and 10 had been in hospital for 14 days or more when they developed their R.S. virus infections, but their illnesses were not associated with a ward outbreak. In each instance there was at least one other child in the ward with R.S. virus infection before the onset of their respiratory illnesses. Case 6, however, may have been infected by his mother who, with a severe cold, visited him during the week preceding his bronchiolitis. Case 12 had been in hospital for only six days. This infection may have been acquired in hospital or outside before admission. Cases 11 and 13 probably acquired their infections at home. For each of these cases, however, there were possible sources of infection in the wards at the time of their admission.

\section{EPIDEMIOLOGY}

The epidemiology of R.S. virus outbreaks is not only hindered by the lack of exact knowledge of the incubation period but also by ignorance of the length of time before the development of clinical symptoms during which infective virus is excreted. Case 5 shows that R.S. virus can be isolated as long as five days before the onset of bronchiolitis, and by immunofluorescence it could be seen that a considerable number of infected cells were present in the nasopharyngeal secretion at that time. It had been hoped to gain further information on this point by taking regular specimens from children who were admitted later on in the outbreak. Though this procedure was followed with six children, none developed respiratory symptoms and none excreted R.S. virus. In adult volunteers experimentally infected with R.S. virus it had been found that the virus can be isolated from the nasopharynx two days before respiratory syinptoms develop (Kravetz et al., 1961; Johnson et al., 1962).

Previous work has shown that R.S. virus antigen is excreted for at least seven days after the onset of symptoms and that the virus can still be isolated at that time in about $25 \%$ of children (Gardner et al., 1971b). Only four of the 13 patients were nursed in wards at the time of their infection with R.S. virus. The remaining nine were in cubicles, and eight of these were nursed with special precaution because of their age. Therefore it is clear that cubicle nursing and the anti-infective procedures associated with it do not protect the infant from cross-infection with R.S. virus. In the present series four children already ill with debilitating conditions were further endangered by a superimposed R.S. virus infection acquired in hospital leading to a severe bronchiolitis. This suggests that the high infectivity of R.S. virus should be taken more seriously and more stringent measures adopted to isolate infants and toddlers with severe illness from diagnosed cases than has hitherto been the custom. As four members of staff were infected with R.S. virus and had mild upper respiratory symptoms, this makes them a potential source of infection and shows how difficult effective prevention will be.

The difficulty in the control of outbreaks in wards is that complete immunity does not develop in adults, who may excrete R.S. virus for short periods of time with minimal symptoms. In this context the rapid diagnosis of R.S. virus infection by the fluorescent antibody technique may prove invaluable in excluding potential sources of infection. The age pattern of the illnesses is important. The five children over 1 year of age developed colds, and the five children aged 3 to 8 months developed bronchiolitis. In three studies of infants with R.S. virus infection in the first months of life bronchiolitis has not been described in the early weeks (Breton et al., 1961; Neligan et al., 1970; Berkovich and Taranko, 1964). In two the virus produced only mild upper respiratory symptoms, in the third the clinical illnesses were either mild colds or pneumonia. In our studies in Newcastle over 10 years we have found that R.S. virus does not cause bronchiolitis in children under 5 weeks of age and this illness is uncommon under 8 weeks. The present study is in keeping with this experience, since two children aged 2 months or less developed colds similar to those in children over 1 year of age, whereas bronchiolitis occurred in all children infected at ages of 3 to 8 months.

Almost all children with bronchiolitis fall into the age range of from 2 to 12 months. The observation that all children in the wards within this age range who became infected with R.S. virus developed bronchiolitis is considered of great interest in relationship to the pathogenesis of this illness (Gardner et al., 1970a).

This study has shown that cubicles, even when special precautions are taken to exclude infection, are not effective in preventing cross-infection with R.S. virus, and one reason is that adults with mild respiratory symptoms may be the vehicle by which R.S. virus is transmitted. Our previous investigations have shown that R.S. virus infections, particularly in infants with congenital heart diseases, can be fatal (Gardner et al., 1967). This is a limited study, but it has shown that crossinfection with R.S. virus can lead to the development of serious illness in children under 1 year of age. It would seem sensible therefore that children of this age, especially those with congenital heart disease, should not be admitted to hospital when R.S. virus is epidemic unless there are strong reasons for doing so.

We are grateful to the medical staff and nurses of all the hospitals involved for their co-operation in this investigation. We are also indebted to the Medical Research Council and the Scientific and Research Subcommittee of the United Newcastle upon Tyne Hospitals for their support.

\section{References}

Beem, M., Wright, F. H., Hamre, D., Egerer, R., and Oehme, M. (1960). New England fournal of Medicine, 263, 523

Berkovich, S., and Taranko, L. (1964). Pediatrics, 34, 753.

Breton, A., Samaille, J., Gaudier, B., Gerard-Lefebvre, and Ponte, C. (1961). Archives francaises de Pédiatrie, 18, 459

Chanock, R. M., et al. (1961). Fournal of the American Medical Association, 176, 647 .

Gardner, P. S. (1968). Archives of Disease in Childhood, 43, 629.

Gardner, P. S., et al. (1967). British Medical fournal, 2, 316.

Gardner, P. S., McQuillin, J., and Court, S. D. M. (1970a). British Medical Fournal, 1,327

Gardner, P. S., McQuillin, J., and McGuckin, R. (1970b). Fournal of Hygiene, 68, 575 .

Gardner, P. S., McQuillin, J., McGuckin, R., and Ditchburn, R. K. (1971). British Medical Fournal, 2, 7

Holzel, A., et al. (1963). Lancet, i, 295

Holzel, A., et al. (1965). British Medical fournal, 1, 614

Hurrell, G. D., Sturdy, P. M., Frood, J. D. L., and Gardner, P. S. (1971). Lancet, 1,769.

Johnson, K. M., Bloom, H. H., Mufson, M. A., and Chanock, R. M. (1962). New England fournal of Medicine, 267, 68 .

Kravetz, H. M., et al. (1961). Fournal of the American Medical Association, 176, 657

176, 657.
McClelland, L., et al. (1961). New England fournal of Medicine, 264, 1169.

McQuillin, J., Gardner, P. S., and Sturdy, P. M. (1970). Fournal of Hygiene, 68, 283.

Neligan, G. A., Steiner, H., Gardner, P. S., and McQuillin, J. (1970). British Medical fournal, 2, 146. Sturdy, P. M., McQuillin, J. and Gardner, P. S. (1969). Fournal of Hygiene,
67, 659. 